\title{
Designing a Controlled Ventilation Onion Storage Structure and Creating Awareness among the Selected Beneficiaries in Erode District
}

\author{
S. Anuradha* \\ Associate Professor, Department of Nutrition and Dietetics, Vellalar College for Women (Autonomous), \\ Erode, India; anusai1986@gmail.com
}

\begin{abstract}
Onion is one of the most important commercial vegetable crops grown on a large scale in India. As the onion is stored for a longer period to use during off season, considerable losses occur by the way of rotting, sprouting, weight loss and moisture evaporation. Modified outdoor and indoor storage structures were developed and the study was carried out to analyze the physical characteristics and nutrient content. No significant result was obtained among the macro nutrients and minerals. The opinion of using indoor storage structure by the beneficiaries was found to be useful. This present study concluded that purchasing of onion at low cost will make the consumer to consume adequate onion during price hike also by using proper storage structures depending upon the onion consumption. Purchasing onion at low cost during glut season also pave the way for the traders to sell the onion at high cost during off-season. Large storage of onion fetches greater profit for the farmers during price hike. Hence this study has given emphasis not only health point of view but also cost benefit to the consumers and traders.
\end{abstract}

Keywords: Controlled Ventilation, Onion Storage Structure

\section{Introduction}

Onion is one of the most important commercial vegetable crops grown in India. Both immature and matured bulbs are used as vegetable and condiment. It contains vitamin $\mathrm{B}$, traces of vitamin $\mathrm{C}$, iron and calcium. The outstanding characteristic of onion is its pungency which is due to a volatile oil known as allyl-propyl disulphide. Onions compared with other fresh vegetable are relatively high in food energy, intermediate in protein content and rich calcium and riboflavin.

Onions are cultivated and used around the world. As a foodstuff they are usually cooked, as a vegetable or as base of a prepared savory dish, but can also be eaten raw or used to make pickles or chutneys. They are pungent when chopped and contain certain chemical substances which irritate the eyes. Onions contain phenolics and flavonoids that have potential anti-inflammatory, anti-cholestrol, anticancer and antioxidant properties. For many people involved in the onion industry the complexity associated with properly storing onions is often overlooked [1]. The fact that we can store onions from one harvest to the next and maintain outstanding quality is taken for granted [2]. The reality is that our ability to hold onions in long term storage and deliver quality product after harvest is directly related to advances in ventilation system design and management. The ventilation system is really the key to maximizing profits from storage. Once the onions are harvested and placed in storage, the ventilation system is the only tool we have to interact with the crop. Anything that we do to the onions will alter the ventilation system. For example, the processes of curing, cooling to holding 
temperature and dehumidification are all driven by the ventilation system and its components. In short, the ventilation system is the life-line to the onions [3].

In order to increase the onion consumption with low cost among the consumers, it is essential to create awareness among the consumers. Avoiding the middle man, fetches direct contact with farmers in turn both farmers and consumers get benefited. The objectives of the present study are to design Controlled Ventilation Onion Storage Structure (CVOSS) with $50 \mathrm{~kg}$ storage capacity as indoor and more than $2000 \mathrm{~kg}$ as outdoor storage structure, to assess the storage losses for 3-6 months of storage, to select beneficiaries based on onion consumption and distribution of CVOSS, to conduct home visits to assess the storage loss, to collect feedback from the selected beneficiaries and to assess the impact of CVOSS on onion storage.

\section{Materials and Methods}

The present study was conducted in Vellalar college for women and around Erode District.

\subsection{Designing of CVOSS (Two Models)}

\subsubsection{Outdoor Storage Structure}

- 10x15 ft (length and breadth) rectangular shaped structure was constructed (Plate -1).

- Four concrete pillars with 3 feet height to prevent entry of pests and contact of moisture from the bottom.

- Triangular shaped roofing to provide proper ventilation and to prevent stagnation of water during rainy season.

- Surrounded by iron mesh to prevent entry of foreign bodies and to provide proper air circulation

- Flooring was done by using wooden reapers to give ventilation

- Iron ropes were tied in cross wise to hang the onion bunches.

\subsubsection{Indoor Storage Structure}

- 3x1.5 (length and breadth) rectangular shaped shelves were made with iron rod (Plate - 2).

- The three shelves were combined and stood by four heavy iron rods as pillars
- One feet height was maintained to prevent damp moisture from the floor and the entry of any pest.

- All sides, including upper side also surrounded by Iron mesh to give proper ventilation.

- Flooring was done by using wooden reapers to give ventilation.

\subsection{Collection and Drying of Onion}

Small onions were collected with the stem in the field directly and dried in sun shade.

\subsection{Methods of Storage}

Four methods of storage was done with the dried onion bunches.

$\mathrm{T}_{1}=$ Tied and Hanged $-\mathrm{TH}($ Plate -3$)$

$\mathrm{T}_{2}=$ Tied and Spread $-\mathrm{TS}$ (Plate -4$)$

$\mathrm{T}_{3}=$ Non-tied and Spread - NS (Plate -5$)$

$\mathrm{T}_{4}=$ Stem removed and Spread - SS (Plate -6$)$

\subsection{Determination of Physical Parameters}

Physical parameters such as weight changes, moisture content, skin color changes, sprouted onion and shrinked onion were estimated before storage and once in a month up to 3 months of storage period.

\subsection{Analysis and Estimation of Nutrients}

Nutrients such as carbohydrate, protein, fat, fiber, vitamin $\mathrm{B}_{1}, \mathrm{~B}_{2}$, Niacin and vitamin $\mathrm{C}$, calcium and Iron were analysed before and after storage period using AOAC method.

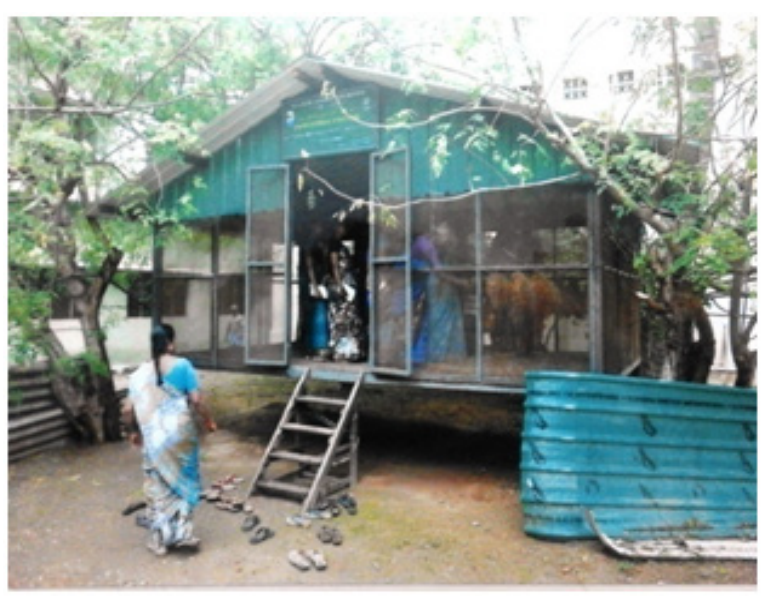

Plate 1. Outdoor storage structure. 


\subsection{Selection of Beneficiaries, \\ Demonstration and Feedback Recording}

Twenty beneficiaries were selected whose family consumes more than $25 \mathrm{~kg}$ for 3 months of period and were provided with CVOSS at free of cost. Awareness was created about onion storage by demonstration. The feedback was collected from the beneficiaries and further improvement in storage structure was suggested.

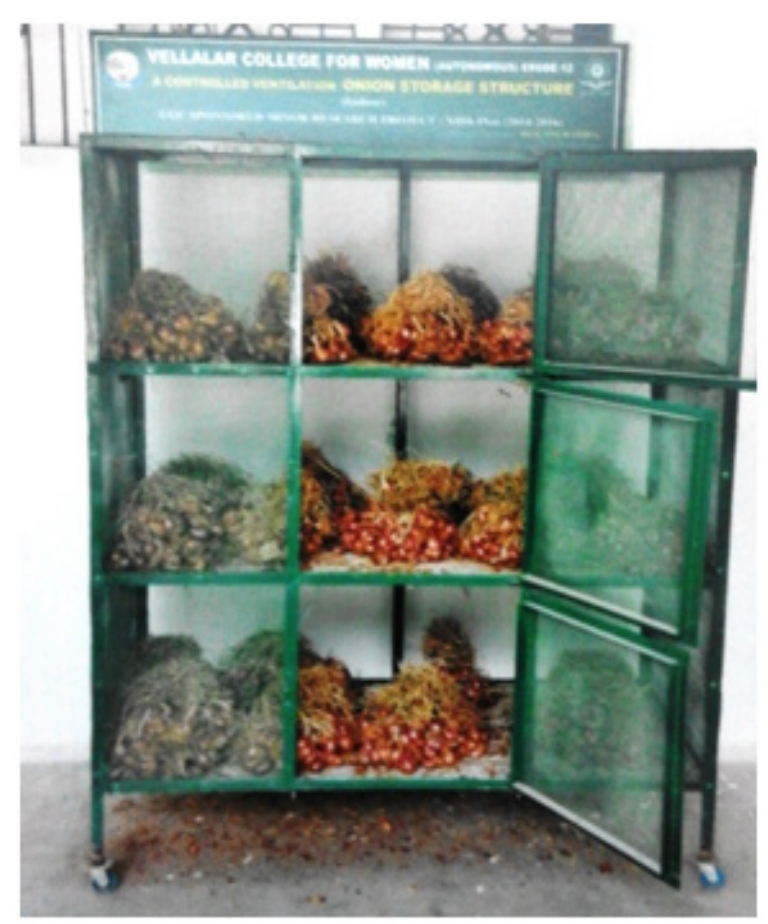

Plate 2. Indoor storage structure.

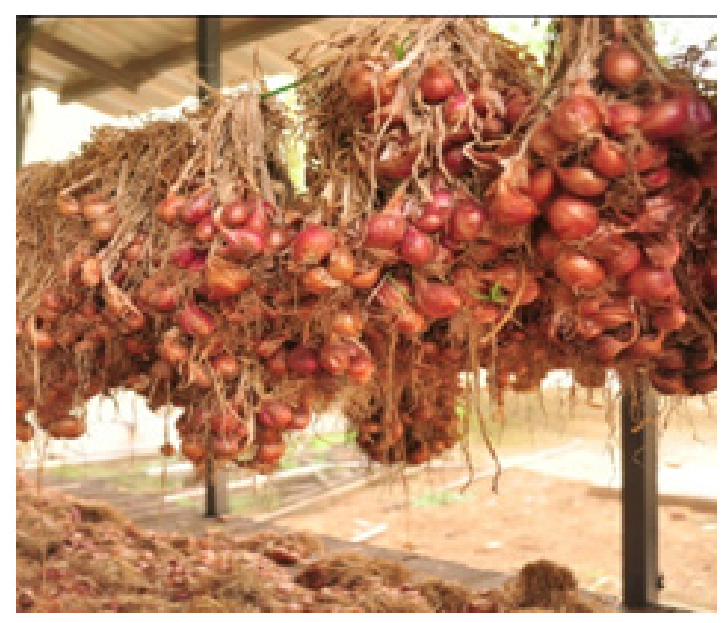

Plate 3. Tied and hanged.

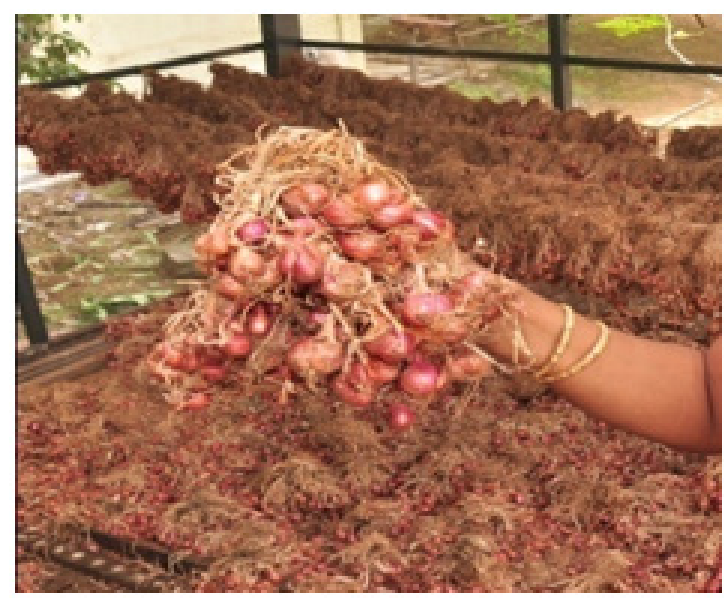

Plate 4. Tied and spread.

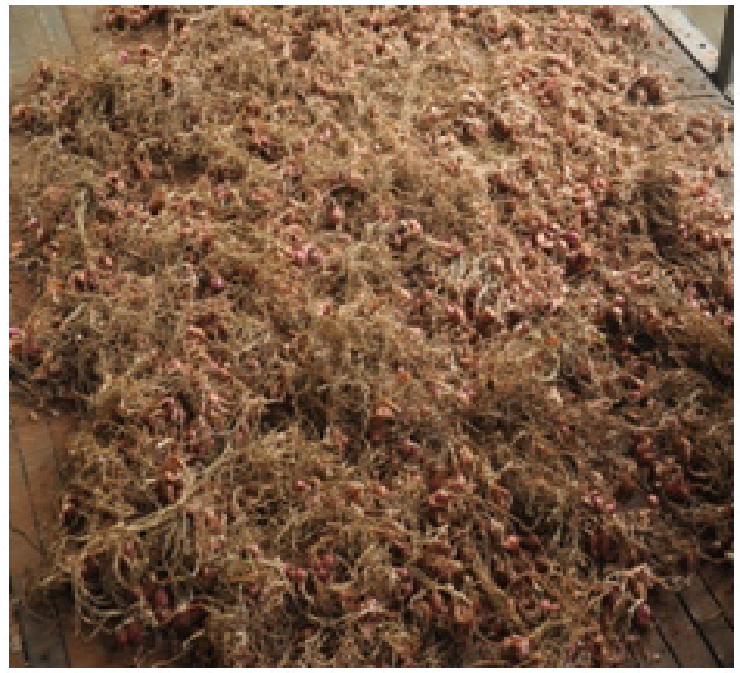

Plate 5. Non-tied and spread.

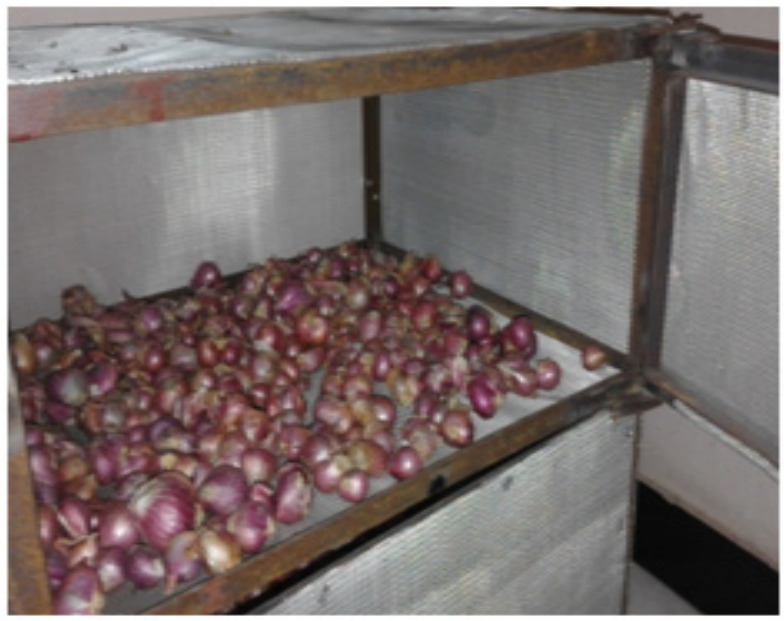

Plate 6. Stem removed and spread. 


\section{Results and Discussion}

Small quantity of onion without stem was purchased and stored for 3 months duration in the ambient condition. The quantity and quality of the onion was assessed for three months, with one month interval period. Black rot spoilage of onion was observed in ambient condition storage, it might be due to sub-soil moisture and improper ventilation. Black rotted onion was removed from the total and the weight was assessed [4].

\subsection{Analysis of Physical Parameters}

\subsubsection{Weight Loss during Storage}

Regarding the weight changes during the study tenure, the weight of the four samples were taken once in a month starting from the storage period up to closure period.
From the Table 1, it was noted that the original weight before storage was found to be same in all samples. During the end of the storage period $\mathrm{T}_{2}$ sample was found to retain 92 per cent weight where as others were $88 \%, 89 \%$ and $85 \%$ respectively. Due to the ventilation, the moisture content also decreased, so that automatically the weight also reduced. Long storage life of onion bulb without having much loss in terms of weight and other quality parameters is the most important for obtaining remunerative price and exporting [5].

\subsubsection{Moisture Content of the Onion Bulb}

Due to aeration and ventilation the moisture content was decreased. Table 2 explains the moisture content of the four samples.

From Table 2, it was understood that the loss of moisture content was more in control sample $\left(\mathrm{T}_{4}\right)$ followed by $\mathrm{T}_{1}, \mathrm{~T}_{3}$ and $\mathrm{T}_{2}$ (Figure 1). It might be due to more drying

Table 1. Changes in weight during storage period (in $\mathrm{Kg}$ )

\begin{tabular}{|c|c|c|c|c|c|c|c|}
\hline \multirow[t]{2}{*}{ S.No. } & \multirow[t]{2}{*}{ Sample } & \multirow{2}{*}{$\begin{array}{l}\text { Before } \\
\text { Storage }\end{array}$} & \multirow{2}{*}{$\begin{array}{l}\text { End of 1st } \\
\text { month }\end{array}$} & \multirow{2}{*}{$\begin{array}{l}\text { End of 2nd } \\
\text { month }\end{array}$} & \multirow{2}{*}{$\begin{array}{l}\text { End of 3rd } \\
\text { month }\end{array}$} & \multicolumn{2}{|c|}{ Difference } \\
\hline & & & & & & $\begin{array}{l}\text { weight loss } \\
\mathrm{Kg} \text { and } \%\end{array}$ & $\begin{array}{c}\text { weight retained } \\
\mathrm{Kg} \text { and } \%\end{array}$ \\
\hline 1 & $\mathrm{~T} 1$ & 100 & 92 & 90 & 88 & 12 & 88 \\
\hline 2 & $\mathrm{~T} 2$ & 100 & 97 & 94 & 92 & 8 & 92 \\
\hline 3 & T3 & 100 & 94 & 91 & 89 & 11 & 89 \\
\hline 4 & $\mathrm{~T} 4$ & 100 & 91 & 89 & 85 & 15 & 85 \\
\hline
\end{tabular}

Table 2. Changes in moisture content during storage (\%)

\begin{tabular}{|l|c|c|c|c|c|c|c|}
\hline S.No. & Sample & $\begin{array}{c}\text { Before } \\
\text { Storage }\end{array}$ & $\begin{array}{c}\text { After One } \\
\text { month }\end{array}$ & $\begin{array}{c}\text { After Two } \\
\text { months }\end{array}$ & $\begin{array}{c}\text { After Three } \\
\text { months }\end{array}$ & Difference & $\begin{array}{c}\text { Retained } \\
\text { moisture }\end{array}$ \\
\hline 1 & T1 & 87 & 82 & 77 & 72 & 15 & 72 \\
\hline 2 & T2 & 87 & 84 & 81 & 78 & 9 & 78 \\
\hline 3 & T3 & 87 & 83 & 79 & 75 & 12 & 75 \\
\hline 4 & T4 & 87 & 81 & 75 & 70 & 17 & 70 \\
\hline
\end{tabular}

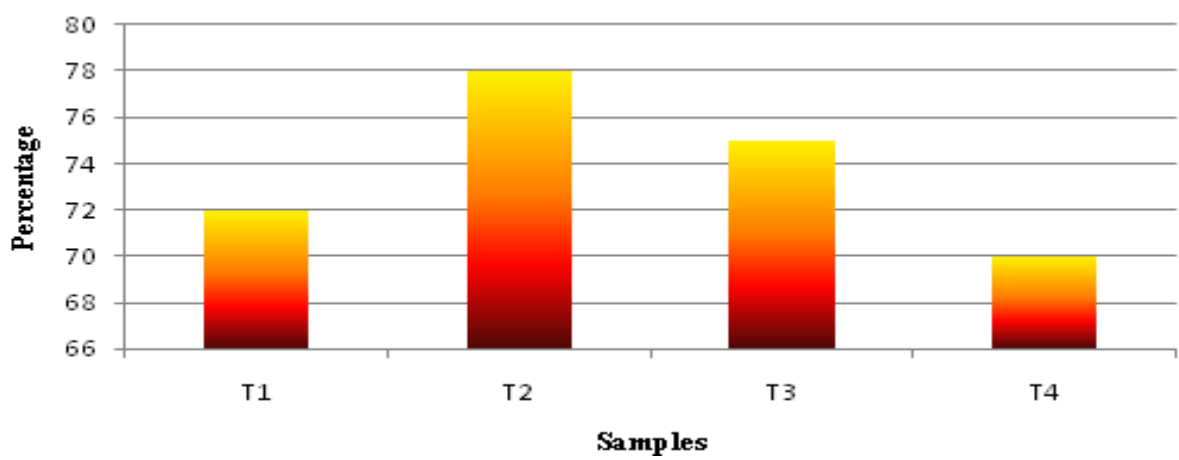

Figure 1. Changes in moisture content during storage. 
process in hanging sample and stem removed sample. Moisture loss kept the onion safe and it could be used for seed purpose also. Microbial damage also reduced due to moisture loss in the samples.

\subsection{Selection of the Best Method of Storing Onion}

Based on the sprouting and shrinking of onion during storage, the storage losses were estimated at the end of $3^{\text {rd }}$ month and presented below.

From the Table 3, the storage loss was maximum (29 percent) in $\mathrm{T}_{4}$ control followed by $\mathrm{T}_{1}$ (tied and hanged) (approximately 18\%), $\mathrm{T}_{3}$ Non-tied and spread (approximately $16 \%$ ) and $\mathrm{T}_{2}$ tied and spread (approximately $13 \%$ ). From this study, the results showed that minimum loss was found in the sample $\mathrm{T}_{2}$ and this method can be best adopted for indoor storage of onion. This method was demonstrated to the beneficiaries to follow and the feedback was collected from the beneficiaries.

\subsection{Analysis of Nutrient Content of Stored Onion}

\subsubsection{Changes in Macro Nutrients during Storage}

Four samples were analyzed for carbohydrate, dietary fiber, fat and protein before and after storage.
The Table 4 illustrated that the macronutrient loss was found to be not-significant at $1 \%$ level, as very little amount of carbohydrates, proteins, fat and fiber was present in the onion, the loss was also very meager. Macronutrients loss was not considered as important in onion storage since the statistical results showed no significant difference.

\subsubsection{Changes in Vitamins Content during Storage}

The water soluble vitamins such as thiamine, niacin and ascorbic acid were analyzed before and after storage.

From the Table 5 it was found that the loss of vitamins was significant at $\mathrm{P}<0.01$ per cent. Thiamin, Niacin and Ascorbic acids were the water soluble and it would be destroyed during drying process and also storage period. Statistically the loss was significant regarding vitamin contents rather than other nutrients.

\subsection{Awareness on Onion Storage}

The beneficiaries were selected based on the consumption of onion more than $25 \mathrm{~kg}$ for 3 months at the house hold level. The questionnaire framed was distributed to 200 subjects in and around the Erode district. Among 200 members, the consumption pattern was assessed and tabulated below. The demonstration classes were conducted in Erode. Twenty members selected among the 200

Table 3. Sprouting and shrinking loss in \%

\begin{tabular}{|l|c|c|c|c|}
\hline S.No. & Sample & Sprouting Loss (\%) & Shrinking Loss (\%) & Total Loss (\%) \\
\hline 1 & T1 & 2.1 & 16 & 18 \\
\hline 2 & T2 & 1.3 & 12 & 13 \\
\hline 3 & T3 & 1.6 & 14 & 16 \\
\hline 4 & T4 & 9.0 & 20 & 29 \\
\hline
\end{tabular}

Table 4. Comparison of macronutrients in different types of storage condition

\begin{tabular}{|l|l|c|c|c|c|c|c|c|c|}
\hline \multirow{2}{*}{ S.No. } & \multirow{2}{*}{ Sample } & \multicolumn{2}{|c|}{ Carbohydrate $(\mathrm{g})$} & \multicolumn{2}{c|}{ Protein (g) } & \multicolumn{2}{c|}{ Fat (g) } & \multicolumn{2}{c|}{ Fiber (g) } \\
\cline { 3 - 10 } & & BS & AS & BS & AS & BS & AS & BS & AS \\
\hline 1 & T1 & 12.6 & 11.8 & 1.7 & 1.5 & 0.1 & 0.08 & 1.1 & 1 \\
\hline 2 & T2 & 12.6 & 12.1 & 1.7 & 1.6 & 0.1 & 0.09 & 1.1 & 1 \\
\hline 3 & T3 & 12.6 & 11.5 & 1.7 & 1.4 & 0.1 & 0.07 & 1.1 & 1 \\
\hline 4 & T4 & 12.6 & 10.8 & 1.7 & 1.1 & 0.1 & 0.06 & 1.1 & 1 \\
\hline Mean & 12.60 & 11.55 & 1.70 & 1.40 & 0.10 & 0.07 & 1.1 & 1 \\
\hline SD & 0 & 0.55 & 0 & 0.21 & 0 & 0.012 & 0 & 0 \\
\hline SE & 0 & 0.27 & 0 & 0.10 & 0 & 0.006 & 0 & 0 \\
\hline & & \multicolumn{3}{|c|}{$\mathrm{t}=3.7717^{*}$} & \multicolumn{2}{|c|}{$\mathrm{t}=2.7775 \mathrm{NS}$} & $\mathrm{t}=3.8730^{*}$ & $\mathrm{t}=1.000 \mathrm{NS}$ \\
\hline
\end{tabular}

AS-After storage BS - Before storage * Significant at 5\% level NS - Not Significant 
Table 5. Changes in Vitamin during Storage Period

\begin{tabular}{|c|c|c|c|c|c|c|c|}
\hline \multirow[t]{2}{*}{ Sl. No } & \multirow[t]{2}{*}{ Sample } & \multicolumn{2}{|c|}{ Thiamin (mg) } & \multicolumn{2}{|c|}{ Niacin (mg) } & \multicolumn{2}{|c|}{ Ascorbic acid (mg) } \\
\hline & & B.S & A.S & B.S & A.S & B.S & A.S \\
\hline 1 & $\mathrm{~T} 1$ & 0.08 & 0.05 & 0.5 & 0.25 & 2 & 1.25 \\
\hline 2 & $\mathrm{~T} 2$ & 0.08 & 0.06 & 0.5 & 0.30 & 2 & 1.50 \\
\hline 3 & T3 & 0.08 & 0.05 & 0.5 & 0.25 & 2 & 1.25 \\
\hline 4 & $\mathrm{~T} 4$ & 0.08 & 0.04 & 0.5 & 0.20 & 2 & 1.00 \\
\hline \multicolumn{8}{|l|}{ t-test : } \\
\hline Mean & & 0.08 & 0.0500 & 0.5 & 0.2500 & 2.0000 & 1.2500 \\
\hline SD & & 0 & 0.0082 & 0 & 0.0408 & 0 & 0.2041 \\
\hline SE & & 0 & 0.0041 & 0 & 0.0204 & 0 & 0.1021 \\
\hline & & \multicolumn{2}{|c|}{$\mathrm{t}=7.3485^{*}$} & \multicolumn{2}{|c|}{$t=9.7980^{*}$} & \multicolumn{2}{|c|}{$\mathrm{t}=7.3485^{*}$} \\
\hline
\end{tabular}

*Significant at 1 per cent level

members were provided with indoor storage structure and the feedback was collected by visiting the houses of the beneficiaries.

\subsection{Cost Calculation}

Procuring onion directly from the field, regularize the cost control, the onion must be purchased from the nearby village to reduce the transport cost.

\subsubsection{Cost Benefit Estimation}

\begin{tabular}{|c|c|c|c|}
\hline \multicolumn{2}{|l|}{ Rate of one kg onion } & \multicolumn{2}{|l|}{ Rs.15.00 } \\
\hline Rate of $25 \mathrm{~kg}$ of onion & $=$ & Rs.375 & \\
\hline Wage for a labor & $=$ & Rs. 50 & \\
\hline Rate of loss \& other exp & penses $=$ & Rs. 50 & \\
\hline Total & $=$ & Rs.475 & \\
\hline One kg. of onion & $=$ Rs. 30 & Rs. 40 & Rs. 50 \\
\hline Total expenses & $=$ Rs. 475 & Rs.475 & Rs. 475 \\
\hline Rate of $25 \mathrm{~kg}$ of onion & $=$ Rs. 750 & Rs.1000 & Rs. 1250 \\
\hline Net profit & $=$ Rs. 275 & Rs. 525 & Rs.775 \\
\hline
\end{tabular}

From the above calculation it is evident that storing onion during glut season brought more profit and the consumption of onion during off-season also gains net profit. The investigator hoped that this project would bring awareness among the public to store the small onion and consume the same amount regularly without bothering about the price hike.

\section{Conclusion}

Present study concluded that the consumers can consume adequate onion during price hike also by using proper storage structures depending upon the onion consumption. Purchasing onion at low cost during glut season also pave the way for the traders to sell the onion at high cost during off-season. Large storage of onion fetches greater profit for the farmers during price hike. Hence this study has given emphasis not only on health point of view but also beneficial cost wise to the consumers and traders.

\section{References}

1. Anbukkarasi V., Paramaguru P., Pugalendhi L., Ragupathi N., and Jayakumar., "Studies on pre and post harvest treatments for extending shelf life in onion", Agricultural Reviews, R1305, p. 256-268, 2010. DOJ: 10.5958/j.09760741.34.4.011

2. Sankar V., Veeraragavathatham D., and Kannan M., "Post harvest storage life of onion influenced by organic farming practices”, Asian J Hort, vol. 4, p. 16-20, 2009.

3. Chope G. A., Terry L.A., and White P. J., "The effect of the transition between controlled atmosphere and regular atmosphere storage bulbs of onion cultivars SS1", Post harvest Biol Technology, vol. 44, p. 228-239, 2007.

4. Dabhi M. N., Patel N. C., and Dhamsaniya N. K., "Effect of storage conditions on the quality characteristics of onion", J Food Sci tech, vol. 45(4), p. 376-377, 2008.

5. Raju K., and Naik M. K., "Effect of Post- harvest treatments of onion to control spoilage during storage", J Food sci Technology, vol. 44(6), p. 595-599, 2007. 